University of Wollongong

Research Online

Faculty of Engineering and Information

Faculty of Engineering and Information

Sciences - Papers: Part A

Sciences

$1-1-2013$

Active shear planes of bolted connections failing in block shear

Drew D. Clements

Hatch,ddac998@uow.edu.au

Lip H. Teh

University of Wollongong, Iteh@uow.edu.au

Follow this and additional works at: https://ro.uow.edu.au/eispapers

Part of the Engineering Commons, and the Science and Technology Studies Commons

Research Online is the open access institutional repository for the University of Wollongong. For further information contact the UOW Library: research-pubs@uow.edu.au 


\title{
Active shear planes of bolted connections failing in block shear
}

\begin{abstract}
In the steel design codes worldwide, the shear area for calculating the block shear capacity of a bolted connection is either the gross or the net shear area. The authors have previously noted independent experimental evidence indicating the shear failure planes to lie midway between the gross and the net shear planes, termed the active shear planes. This paper presents the nonlinear contact finite brick element analysis results that confirm the location of the active shear planes, indicated by regions of maximum shear stresses. The finite-element analysis also found that shear stresses approach zero toward the free downstream end of the connection block. The veracity of the active shear area is further demonstrated in terms of the ability of the resulting block shear equation to predict the governing failure modes of test specimens consistently, in comparison with the equations assuming the gross and the net shear areas.
\end{abstract}

\section{Keywords}

failing, planes, connections, block, bolted, active, shear

Disciplines

Engineering | Science and Technology Studies

\section{Publication Details}

Clements, D. D. \& Teh, L. H. (2013). Active shear planes of bolted connections failing in block shear. Journal of Structural Engineering, 139 (3), 320-327. 


\title{
Active Shear Planes of Bolted Connections Failing in Block Shear
}

\author{
Drew D. A. Clements ${ }^{1}$ and Lip H. Teh, A.M.ASCE ${ }^{2}$
}

\begin{abstract}
In the steel design codes worldwide, the shear area for calculating the block shear capacity of a bolted connection is either the gross or the net shear area. The authors have previously noted independent experimental evidence indicating the shear failure planes to lie midway between the gross and the net shear planes, termed the active shear planes. This paper presents the nonlinear contact finite brick element analysis results that confirm the location of the active shear planes, indicated by regions of maximum shear stresses. The finite-element analysis also found that shear stresses approach zero toward the free downstream end of the connection block. The veracity of the active shear area is further demonstrated in terms of the ability of the resulting block shear equation to predict the governing failure modes of test specimens consistently, in comparison with the equations assuming the gross and the net shear areas. DOI: 10.1061/(ASCE)ST.1943-541X.0000626. ${ }^{\circ}$ 2013 American Society of Civil Engineers.
\end{abstract}

CE Database subject headings: Bolted connections; Cold-formed steel; Shear failures; Steel plates; Tensile strength.

Author keywords: Bolted connections; Cold-formed steel; Shear failures; Steel plates; Tensile strength.

\section{Introduction}

Block shear failure is recognized as a strength limit state of bolted connections in the American Institute of Steel Construction (AISC) Specification for Structural Steel Buildings (AISC 2010), the North American Specification for the Design of Cold-formed Steel Structural Members 2007 [American Iron and Steel Institute (AISI) 2010], Eurocode 3, Part 1.8 [European Committee for Standardization (CEN) 2005], and AS/NZS 4600:2005 Cold-formed Steel Structures [Standards Australia/Standards New Zealand (SA/SNZ) 2005]. However, since it was discovered by Birkemoe and Gilmor (1978) and first incorporated into the AISC specification (AISC 1978), the design provision for determining the block shear capacity of a bolted connection has continued to change and even oscillate between certain equations, as described by Teh and Clements (2012). The reasons are at least twofold.

First, there was the uncertainty concerning the possible mechanisms for block shear failures. Recently, Teh and Clements (2012) explained that a conventional block shear failure can only occur by the shear yielding and tensile rupture mechanism, as borne out by extensive experimental tests (Hardash and Bjorhovde 1985; Seleim and LaBoube 1996; Huns et al. 2006; Teh and Clements 2012).

The more important factor, however, is the use of the gross and the net areas in computing the yielding and the rupture resistance terms, respectively. The gross shear area is used when the failure

${ }^{1}$ Graduate Structural Engineer, Hatch, 25 Atchinson Street, Wollongong, NSW 2500, Australia; formerly, Honours Student, School of Civil, Mining and Environmental Engineering, Univ. of Wollongong, Wollongong, NSW 2500, Australia.

${ }^{2}$ Senior Lecturer, School of Civil, Mining and Environmental Engineering, Univ. of Wollongong, Wollongong, NSW 2500, Australia (corresponding author). E-mail: lteh@uow.edu.au

Note. This manuscript was submitted on December 14, 2011; approved on March 30, 2012; published online on April 14, 2012. Discussion period open until August 1, 2013; separate discussions must be submitted for individual papers. This paper is part of the Journal of Structural Engineering, Vol. 139, No. 3, March 1, 2013. CASCE, ISSN 07339445/2013/3-320-327/\$25.00. mechanism is shear yielding and tensile rupture (AISC 1986, 2010), whereas the net shear area is used for the supposed shear rupture and tensile yielding mechanism (AISC 1986, 1999) or simultaneous shear and tensile rupture mechanism (AISC 1978, 2010). Such an approach is not logical because yielding must precede rupture, and the failure planes should be unique as they relate to the same failure mode, irrespective of the mechanism. The inconsistent definitions for the failure planes give rise to unnecessary anomalies that led to repeated amendments to the design provision. In this regard, Teh and Clements (2012) noted the experimental evidence of Franchuk et al. (2003) that suggests the shear failure planes to lie midway between the gross and the net shear planes and proposed a design equation for determining the block shear capacity using the so-called active shear planes.

The equation proposed by Teh and Clements (2012) was demonstrated to be more accurate than all equations existing in the literature in predicting the block shear failure loads of laboratory test specimens. However, Cunningham et al. (1995) showed that a mean professional factor close to unity can always be achieved through regression analysis of the concerned data for any mechanism arbitrarily assumed for the block shear failures.

In this paper, the experimental evidence of Franchuk et al. (2003) will be examined through geometrically and materially nonlinear contact finite-element analysis (FEA) using ABAQUS 6.9. Previous finite-element investigations of block shear failures of bolted connections have been carried out by Topkaya (2004), Huns et al. (2006), Kim and Kuwamura (2007), and Liao et al. (2011). However, no identification of the active shear planes in the block shear failure of a bolted connection has ever been published.

The active shear planes will also be verified in terms of the ability of the resulting block shear equation to predict the governing failure modes of test specimens consistently in comparison with the equations assuming the gross and the net shear areas.

\section{Relevant Equations for Block Shear Capacity}

Because Teh and Clements (2012) have explained and demonstrated that a conventional block shear failure invariably fails by the shear 
yielding and tensile rupture mechanism, as borne out by laboratory test results, the present work is only concerned with the equations that are based on such a mechanism. There are therefore only three equations to consider.

The first equation is found in the North American specifications (AISC 2010; AISI 2010) and the Australasian standard (SA/SNZ 2005)

$$
P_{p}=F_{u} A_{n t}+0.6 F_{y} A_{g v}
$$

where $F_{u}=$ material tensile strength, $F_{y}=$ yield stress, $A_{n t}=$ net tensile area, and $A_{g v}=$ gross shear area. The implied block is depicted in Fig. 1(a), which shows that the shear planes assumed in Eq. (1) lie at the outer perimeter of the block.

The second equation to consider is found in the European code (CEN 2005)

$$
P_{p}=F_{u} A_{n t}+\frac{F_{y} A_{n v}}{\sqrt{3}} \approx F_{u} A_{n t}+0.577 F_{y} A_{n v}
$$

where $A_{n v}=$ net shear area indicated in Fig. 1(b). This approach, which departs from the AISC's longstanding tradition for shear yielding plane and from the earlier Eurocode (CEN 1992), ignores the fact that the planes coinciding with the centerlines of the bolt holes in the direction of loading do not have maximum shear stresses as a result of the bolt bearing condition.

The third equation was proposed by Teh and Clements (2012)

$$
P_{p}=F_{u} \sum A_{n t}\left(0.9+0.1 \frac{d}{p_{2}}\right)+0.6 F_{y} A_{a v}
$$

where $A_{a v}=$ active shear area defined in Fig. 2. The variable $d$ denotes the bolt diameter, whereas $p_{2}$ is defined in Fig. 3. The active shear area has been used by Teh and Clements (2012) based partially on the experimental evidence of Franchuk et al. (2003) shown in figure 3 of their paper. The specimens were tested by Franchuk et al. (2003) to fracture along the shear planes, enabling the identification of the active shear planes.

Eq. (3) incorporates an in-plane shear lag factor proposed by Teh and Gilbert (2012) in determining the net section tension capacity.

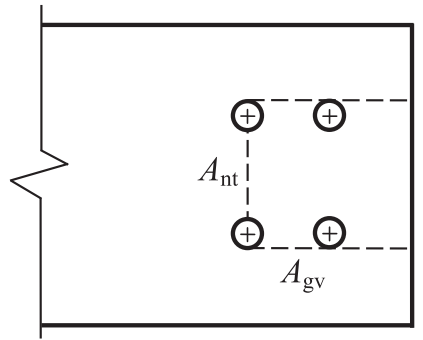

(a)

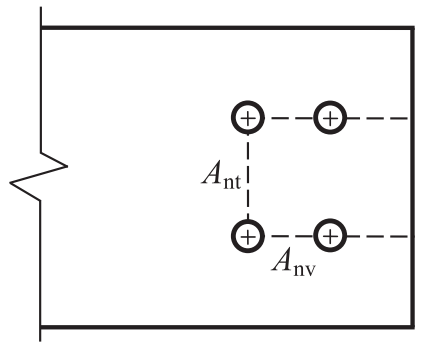

(b)

Fig. 1. (a) Gross shear planes; (b) net shear planes
The shear lag factor accounts for the fact that the tensile stresses are not uniformly distributed across the net section, which has a significant effect on the tension capacity of bolted connections in coldreduced sheet steel.

\section{Finite-Element Analysis to Locate the Active Shear Planes}

The finite-element models simulate concentrically loaded bolted connections in steel sheets, an example of which is shown in Fig. 4

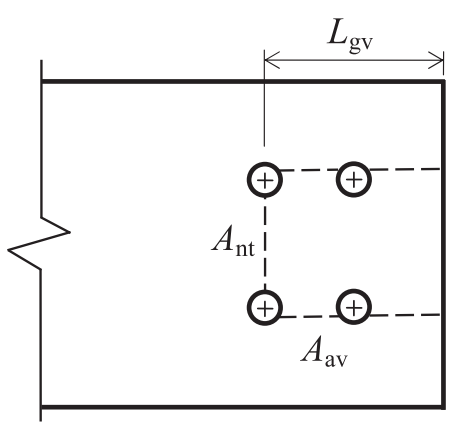

$$
\begin{gathered}
L_{a v}=L_{g v}-\left(\frac{n_{r}-1}{2}+\frac{1}{4}\right) d_{h} \\
\approx L_{g v}-n_{r} d_{h} / 2 \\
A_{a v}=2 L_{a v} t
\end{gathered}
$$

Fig. 2. Active shear planes

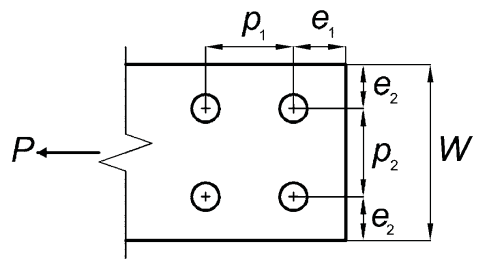

Fig. 3. Definitions of geometric variables
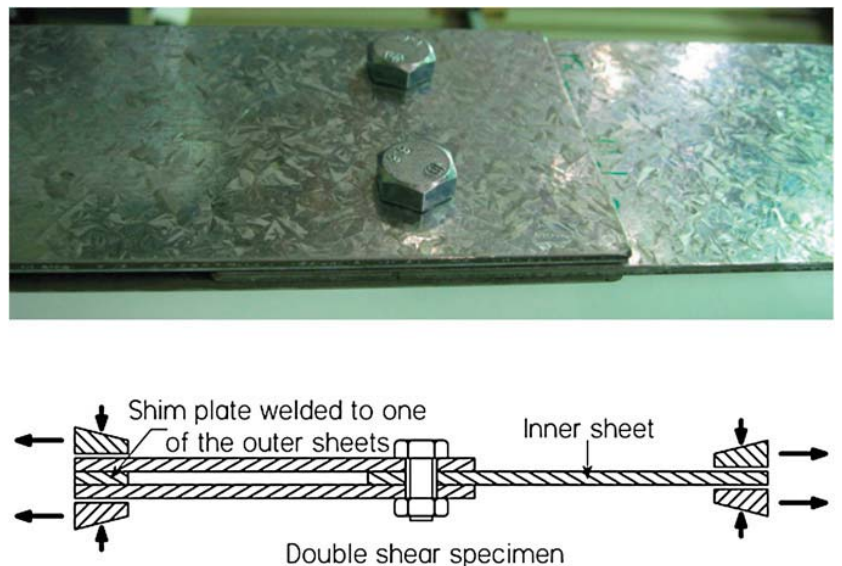

Fig. 4. Concentrically loaded inner sheet 


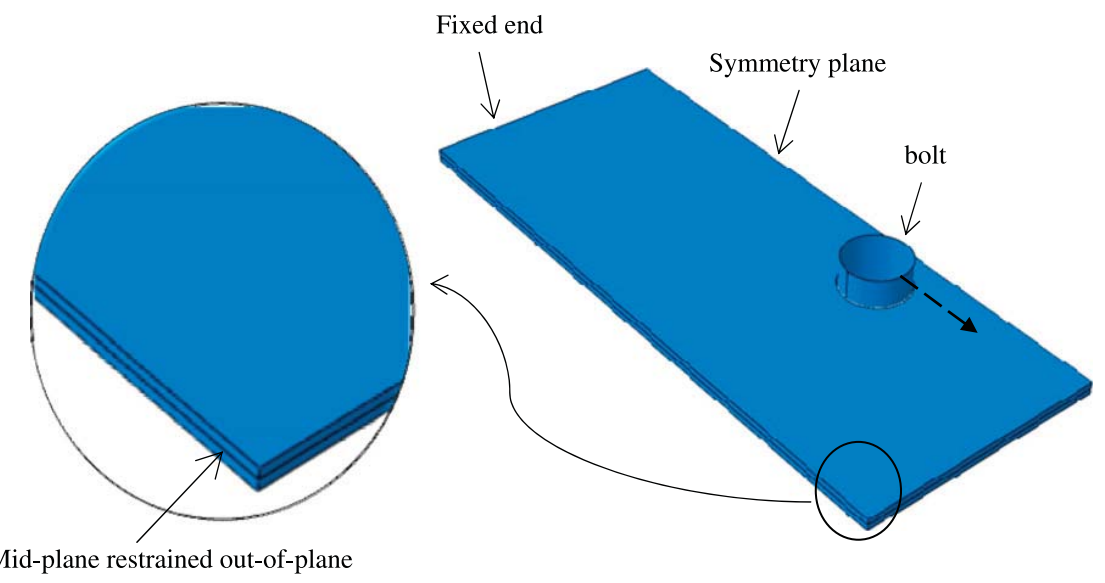

Fig. 5. Conceptual model (one row of bolts)

for a specimen with one row of bolts. It is the inner sheet subjected to double shear that was modeled in the FEA.

Because of symmetry, only half of the concentrically loaded sheet was modeled as shown in Fig. 5, with transverse displacements prevented across the symmetry plane. Rotation about the symmetry axis was also prevented. The left end was completely restrained (fixed), and only the midplane of the sheet, indicated by the lines running along the middle of the sheet thickness, was restrained out-of-plane so that necking through the sheet thickness was not prevented. The hexahedral reduced integration brick element type C3D8R available in ABAQUS 6.9 was used so that each finite-element model was three-dimensional (3D). Fig. 6 shows an example of the finiteelement mesh.

The analysis was geometrically and materially nonlinear using the true stress-strain curves shown in Fig. 7(a), which were derived by matching the tension coupon test results, as illustrated in Fig. 7(b), for the $3.0-\mathrm{mm}$ G450 sheet steel coupon. In the elastic range, the simulated response is stiffer than that apparently exhibited by the tension coupon, perhaps because of some flexibility or slippage in the testing system. The FEA assumed an elastic modulus of $200 \mathrm{GPa}$, which may be higher than the reality. Once the material yielded, the stroke displacements were almost entirely caused by inelastic straining.

The relevant true stress and strain values, which were used in the FEA, are given in Table 1 . The plasticity of the steel material was handled through the von Mises yield criterion and the Prandtl-Reuss flow rule with isotropic hardening. The true shear yield stress $\tau_{y}$ of the $1.5-\mathrm{mm}$ sheet steel is therefore approximately $355 \mathrm{MPa}$ and that of the 3.0-mm sheet steel is $320 \mathrm{MPa}$. The Poisson's ratio is assumed to be 0.3 .

Loading of the connection was simulated by displacing the bolt away from the fixed end as indicated by the dashed arrow in Fig. 5, which would be resisted by the contact surface between the bolt and the bolt hole at the downstream end. The bolt was modeled as a 3D analytical rigid body revolved shell, and the bolt hole had a diameter that was $1 \mathrm{~mm}$ larger than the bolt, as was the case with the laboratory test specimens.

Although the present finite-element models do not simulate fracture, they are capable of predicting the block shear capacity of a bolted connection defined as the limit load in Fig. 8. As explained by Teh and Clements (2012), tensile fracture only takes place in the net section between bolt holes after the displacement corresponding to the limit load has passed. The limit load is reached when necking

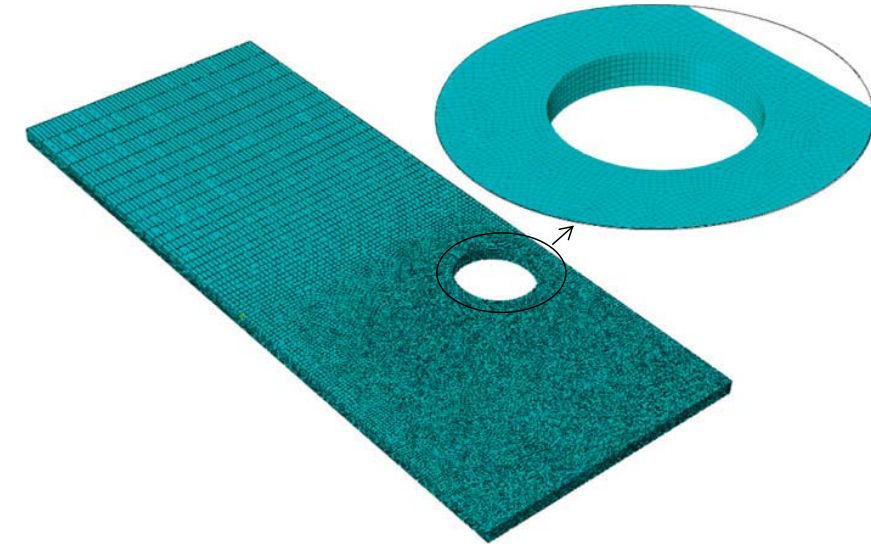

Fig. 6. Finite brick element (C3D8R) mesh

in the net section is such that the applied load has to decrease to maintain static equilibrium. In Fig. 8, the abrupt drop in the applied load corresponds to the tensile fracture across the net section between bolt holes (at the upstream end for a connection with multiple rows of bolts).

The reliability of the present finite-element models in closely replicating the ultimate test loads obtained by Teh and Clements (2012) has been demonstrated in Clements (2011), as reproduced in Tables 2 and 3. Series A specimens had one row of bolts only, whereas Series B specimens had two rows of bolts. An example of each is shown in Fig. 9.

The variable $P_{t}$ in the tables denotes the ultimate test loads obtained in the experiment of Teh and Clements (2012). The ratio $P_{t} / P_{p}$ is therefore the professional factor of a method or equation for determining $P_{p}$. The variable $t$ is the nominal sheet thickness; all other geometric variables are defined in Fig. 3. The finite-element models used the nominal values.

Tables 2 and 3 also show the ratios of the ultimate test load to predicted failure load computed using Eqs. (1)-(3). The engineering properties substituted into the equations are given in Table 4 , which lists the average base metal thicknesses $t_{\text {base }}$, yield stresses $F_{y}$, tensile strengths $F_{u}$, and elongations at fracture over 15-, 25-, and 50 -mm gauge lengths $\left(\varepsilon_{15}, \varepsilon_{25}\right.$, and $\varepsilon_{50}$, respectively) and uniform elongation outside fracture $\varepsilon_{u o}$ of the 1.5- and 3.0-mm sheet steels. 


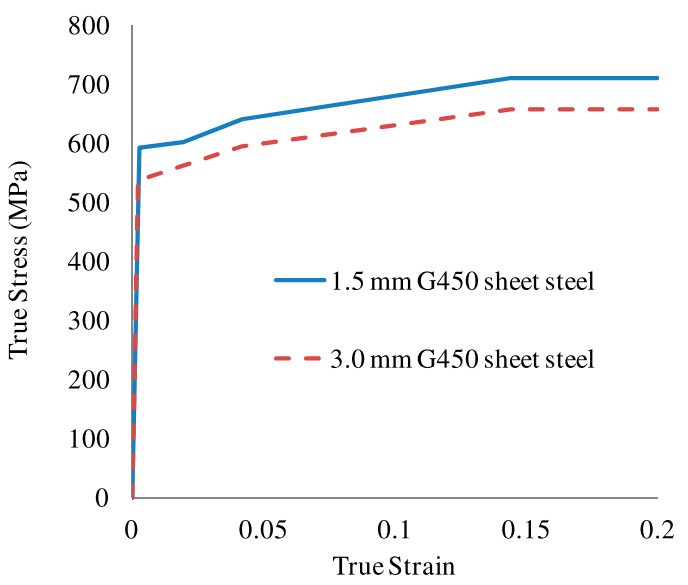

(a)

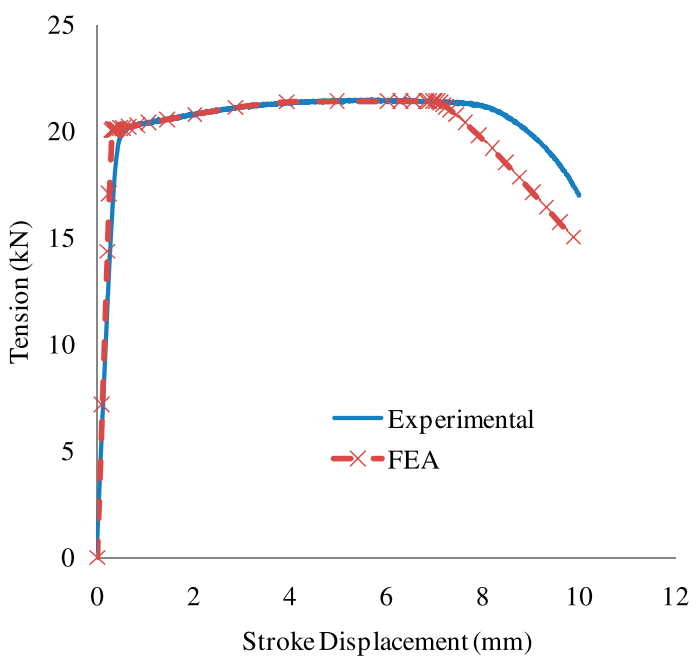

(b)

Fig. 7. Modeling of material behavior: (a) true stress-strain curves; (b) response calibration of 3.0-mm coupon

Table 1. True Stress-Strain Data for FEA

\begin{tabular}{|c|c|c|c|c|c|c|}
\hline \multirow[b]{2}{*}{ Point } & \multicolumn{3}{|c|}{$1.5-\mathrm{mm} \mathrm{G} 450$ sheet steel } & \multicolumn{3}{|c|}{ 3.0-mm G450 sheet steel } \\
\hline & $\begin{array}{c}\text { True strain } \\
\left(10^{-3}\right)\end{array}$ & $\begin{array}{l}\text { Plastic strain } \\
\quad\left(10^{-3}\right)\end{array}$ & $\begin{array}{c}\text { True stress } \\
(\mathrm{MPa})\end{array}$ & $\begin{array}{c}\text { True strain } \\
\left(10^{-3}\right)\end{array}$ & $\begin{array}{c}\text { Plastic } \\
\text { strain } \\
\left(10^{-3}\right)\end{array}$ & $\begin{array}{c}\text { True } \\
\text { stress } \\
\text { (MPa) }\end{array}$ \\
\hline 1 & 0 & 0 & 0 & 0 & 0 & 0 \\
\hline 2 & 3.02 & 0.00 & 590 & 2.64 & 0.00 & 535 \\
\hline 3 & 19.8 & 16.8 & 600 & 41.9 & 39.3 & 595 \\
\hline 4 & 41.9 & 38.9 & 640 & 144 & 141 & 660 \\
\hline 5 & 144 & 141 & 710 & 1,000 & 997 & 660 \\
\hline 6 & 1,000 & 997 & 710 & - & - & - \\
\hline
\end{tabular}

All the equations used the measured geometric dimensions (Teh and Clements 2012).

Fig. 10 shows the true in-plane shear stress contours of Specimen CPD14. It can be seen that the largest shear stresses take place along a shear plane that is midway between the gross and the net shear planes indicated in Fig. 1. The active shear planes depicted in Fig. 2 represent the FEA results most closely.

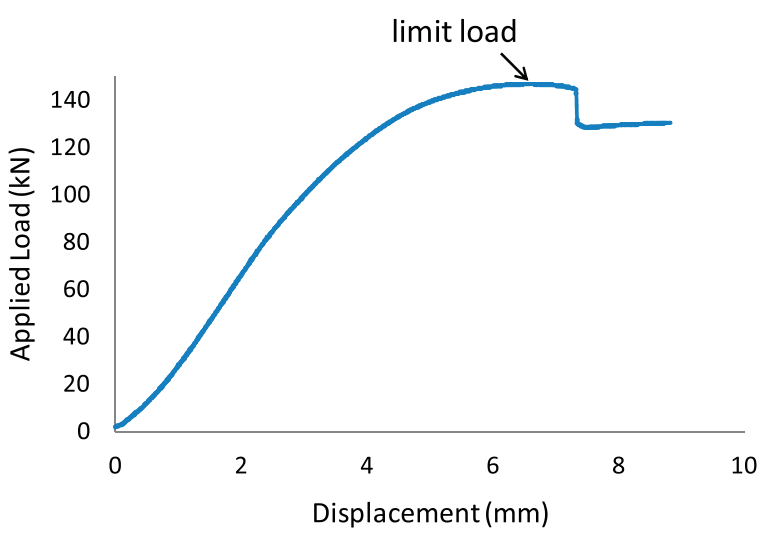

Fig. 8. Definition of block shear capacity

Table 2. Professional Factors for Series A Specimens

\begin{tabular}{|c|c|c|c|c|c|c|c|c|c|}
\hline \multirow[b]{2}{*}{ Specimen } & \multirow{2}{*}{$\begin{array}{c}W \\
(\mathrm{~mm})\end{array}$} & \multirow{2}{*}{$\begin{array}{c}p_{2} \\
(\mathrm{~mm})\end{array}$} & \multirow{2}{*}{$\begin{array}{c}t \\
(\mathrm{~mm})\end{array}$} & \multirow{2}{*}{$\begin{array}{c}e_{1} \\
(\mathrm{~mm})\end{array}$} & \multirow{2}{*}{$\begin{array}{c}d_{h} \\
(\mathrm{~mm})\end{array}$} & \multicolumn{4}{|c|}{$P_{t} / P_{p}$} \\
\hline & & & & & & FEA & 1 & 2 & 3 \\
\hline CPD14 & 100 & 33 & 1.5 & 50 & 17 & 1.10 & 0.80 & 0.95 & 0.95 \\
\hline CPD15 & 100 & 33 & 3.0 & 50 & 13 & - & 0.90 & 1.02 & 1.01 \\
\hline CPD16 & 100 & 33 & 3.0 & 50 & 17 & 1.05 & 0.89 & 1.06 & 1.04 \\
\hline CPD18 & 120 & 40 & 1.5 & 50 & 17 & 0.99 & 0.86 & 1.01 & 1.00 \\
\hline CPD19 & 120 & 40 & 3.0 & 50 & 13 & - & 0.90 & 1.01 & 1.01 \\
\hline CPD20a & 120 & 40 & 3.0 & 50 & 17 & 0.98 & 0.93 & 1.08 & 1.07 \\
\hline CPD20b & 120 & 40 & 3.0 & 50 & 17 & 0.98 & 0.93 & 1.07 & 1.07 \\
\hline CPD22a & 100 & 26 & 1.5 & 50 & 17 & 1.14 & 0.81 & 0.99 & 0.96 \\
\hline CPD22b & 100 & 26 & 1.5 & 50 & 17 & 1.11 & 0.83 & 1.02 & 0.99 \\
\hline CPD23a & 100 & 26 & 3.0 & 50 & 13 & - & 0.90 & 1.03 & 1.01 \\
\hline CPD23b & 100 & 26 & 3.0 & 50 & 13 & - & 0.89 & 1.02 & 1.01 \\
\hline CPD24a & 100 & 26 & 3.0 & 50 & 17 & 1.05 & 0.87 & 1.05 & 1.02 \\
\hline CPD24b & 100 & 26 & 3.0 & 50 & 17 & 1.04 & 0.87 & 1.05 & 1.02 \\
\hline CPD26a & 120 & 26 & 1.5 & 50 & 17 & 1.06 & 0.85 & 1.03 & 1.01 \\
\hline CPD26b & 120 & 26 & 1.5 & 50 & 17 & 1.07 & 0.84 & 1.02 & 1.00 \\
\hline CPD27 & 120 & 26 & 3.0 & 50 & 13 & - & 0.91 & 1.04 & 1.02 \\
\hline CPD28a & 120 & 26 & 3.0 & 50 & 17 & 1.03 & 0.91 & 1.09 & 1.06 \\
\hline CPD28b & 120 & 26 & 3.0 & 50 & 17 & 1.05 & 0.89 & 1.07 & 1.04 \\
\hline CPD36 & 130 & 45 & 3.0 & 30 & 17 & 1.03 & 0.94 & 1.11 & 1.13 \\
\hline Mean & - & - & - & - & - & 1.05 & 0.88 & 1.04 & 1.02 \\
\hline $\begin{array}{l}\text { Coefficient } \\
\text { of variation }\end{array}$ & - & - & - & - & - & 0.044 & 0.044 & 0.038 & 0.041 \\
\hline
\end{tabular}

It can also be seen that the largest shear stresses only take place within a short portion of each active shear plane, with the shear stresses approaching zero toward the downstream end. It is evident from Tables 2 and 3 that Eq. (3) provides accurate estimates of the ultimate test loads of laboratory specimens. As shown in Fig. 2, the active shear area $A_{a v}$ in Eq. (3) is calculated by ignoring a portion of each active shear plane over a length equal to a quarter of the bolt hole diameter. This neglect is supported by the shear stress contours in Fig. 10.

It may be noted that the shear stress contours indicate that shearout is nowhere near being the governing failure mode for Specimen CPD14. The shear stresses closer to the symmetry plane (on the left side) are much lower than those on the active shear plane caused by the lesser stiffness offered by the region associated with the net section between bolt holes.

Fig. 11 shows the true in-plane shear stress contours of Specimen CQ5, which had two rows of bolts. As with CPD14, which had one row of bolts only, the active shear planes are still best represented by 
Table 3. Professional Factors for Series B Specimens $\left(p_{1}=30 \mathrm{~mm}\right)$

\begin{tabular}{|c|c|c|c|c|c|c|c|c|c|}
\hline \multirow[b]{2}{*}{ Specimen } & \multirow{2}{*}{$\begin{array}{c}W \\
(\mathrm{~mm})\end{array}$} & \multirow{2}{*}{$\begin{array}{c}p_{2} \\
(\mathrm{~mm})\end{array}$} & \multirow{2}{*}{$\begin{array}{c}t \\
(\mathrm{~mm})\end{array}$} & \multirow{2}{*}{$\begin{array}{c}e_{1} \\
(\mathrm{~mm})\end{array}$} & \multirow{2}{*}{$\begin{array}{c}d_{h} \\
(\mathrm{~mm})\end{array}$} & \multicolumn{4}{|c|}{$P_{t} / P_{p}$} \\
\hline & & & & & & FEA & 1 & 2 & 3 \\
\hline CQ2a & 120 & 26 & 1.5 & 50 & 17 & 1.09 & 0.73 & 1.08 & 0.92 \\
\hline CQ2b & 120 & 26 & 1.5 & 50 & 17 & 1.07 & 0.74 & 1.09 & 0.93 \\
\hline CQ3 & 120 & 26 & 3.0 & 50 & 13 & 1.03 & 0.85 & 1.12 & 1.00 \\
\hline CQ4 & 120 & 26 & 3.0 & 50 & 17 & 1.03 & 0.80 & 1.15 & 0.99 \\
\hline CQ5a & 130 & 40 & 1.5 & 30 & 13 & 1.02 & 0.82 & 1.10 & 0.99 \\
\hline CQ5b & 130 & 40 & 1.5 & 30 & 13 & 1.04 & 0.81 & 1.08 & 0.98 \\
\hline CQ6a & 130 & 40 & 1.5 & 30 & 17 & 1.07 & 0.77 & 1.14 & 0.98 \\
\hline CQ6b & 130 & 40 & 1.5 & 30 & 17 & 1.06 & 0.77 & 1.14 & 0.99 \\
\hline CQ7 & 130 & 40 & 3.0 & 30 & 13 & 1.00 & 0.89 & 1.17 & 1.07 \\
\hline CQ8 & 130 & 40 & 3.0 & 30 & 17 & 1.04 & 0.83 & 1.22 & 1.06 \\
\hline CQ9b & 130 & 55 & 1.5 & 30 & 13 & 1.07 & 0.81 & 1.04 & 0.97 \\
\hline CQ10a & 130 & 55 & 1.5 & 30 & 17 & 1.06 & 0.78 & 1.08 & 0.98 \\
\hline CQ10b & 130 & 55 & 1.5 & 30 & 17 & 1.05 & 0.80 & 1.10 & 1.00 \\
\hline CQ11 & 130 & 55 & 3.0 & 30 & 13 & 0.99 & 0.87 & 1.09 & 1.03 \\
\hline CQ12 & 130 & 55 & 3.0 & 30 & 17 & 1.04 & 0.85 & 1.17 & 1.06 \\
\hline Mean & - & - & - & - & - & 1.04 & 0.81 & 1.12 & 1.00 \\
\hline $\begin{array}{l}\text { Coefficient } \\
\text { of variation }\end{array}$ & - & - & - & - & - & 0.027 & 0.055 & 0.042 & 0.044 \\
\hline
\end{tabular}

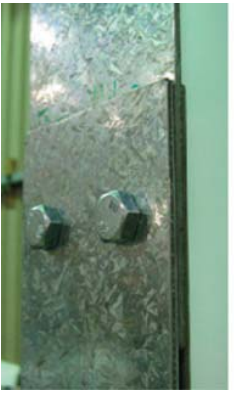

(a) Series A

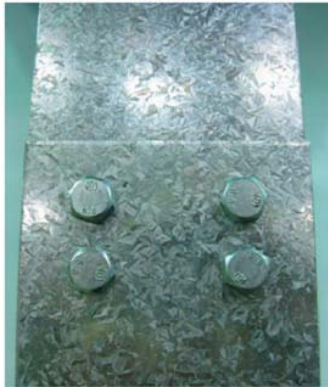

(b) Series B
Fig. 9. Bolting configurations of Series A and B specimens: (a) Series A; (b) Series B

Table 4. Measured Engineering Properties

\begin{tabular}{lcc}
\hline & \multicolumn{2}{c}{ Value } \\
\cline { 2 - 3 } Property & $1.5-\mathrm{mm}$ sheet steel & 3.0-mm sheet steel \\
\hline$t_{\text {base }}(\mathrm{mm})$ & 1.48 & 2.95 \\
$F_{y}(\mathrm{MPa})$ & 605 & 530 \\
$F_{u}(\mathrm{MPa})$ & 630 & 580 \\
$F_{u} / F_{y}$ & 1.04 & 1.09 \\
$\varepsilon_{15}(\%)$ & 21.3 & 29.3 \\
$\varepsilon_{25}(\%)$ & 18 & 22 \\
$\varepsilon_{50}(\%)$ & 12 & 15.3 \\
$\varepsilon_{v o}(\%)$ & 6.8 & 8.1 \\
\hline
\end{tabular}

Fig. 2. The shear stress contours also support the formula for determining the active shear area $A_{a v}$ shown in Fig. 2.

\section{Further Verification of the Active Shear Planes}

Tables 2 and 3 show that Eq. (3), which makes use of the active shear planes defined in Fig. 2, is significantly more accurate than Eqs. (1)

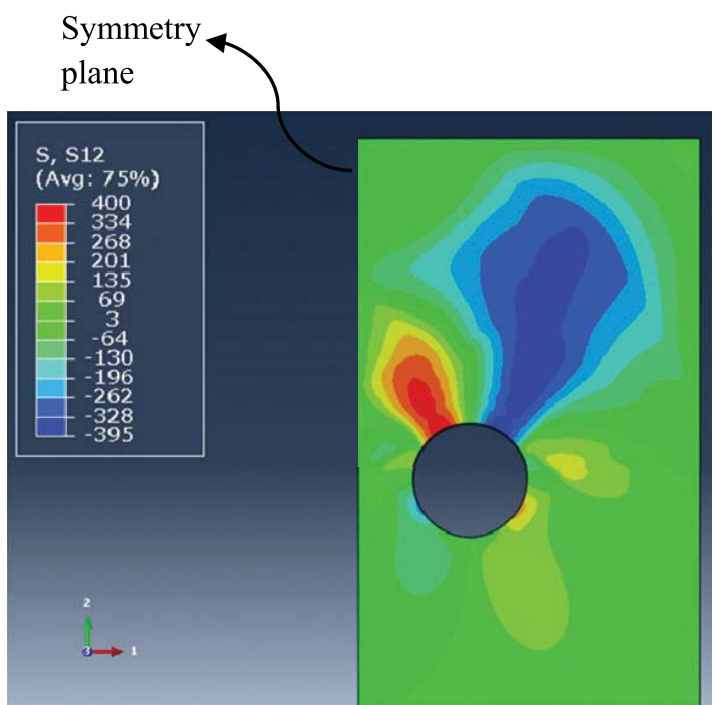

Fig. 10. In-plane shear stresses of CPD14

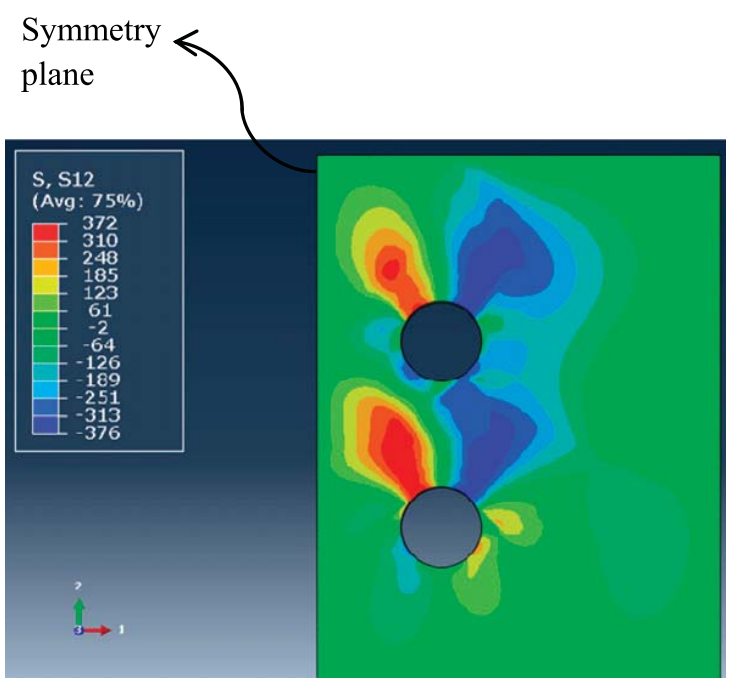

Fig. 11. In-plane shear stresses of CQ5

and (2) in estimating the block shear failure loads. Hypothetically, an incorrect equation may give more accurate estimates than a correct equation does if the material and/or geometric properties used in the calculations are not accurate representations of the actual specimens. In fact, if the nominal material properties of the G450 sheet steels are used in the calculations, Eq. (1) would be found to give more accurate results than Eq. (3). In theory, it is possible, for example, that the measured tensile strengths used in the calculations for Tables 2 and 3 were too high, skewing the results in favor of Eq. (3) against Eq. (1).

The uncertainties described in the preceding paragraph can be resolved by checking the ability of each block shear equation to predict the governing failure modes of the test specimens that either failed in block shear as shown in Fig. 12(a) or net section tension fracture as shown in Fig. 12(b). The governing failure mode is identified by comparing the block shear capacity against the net section tension capacity, both computed using the same measured material and geometric properties. 


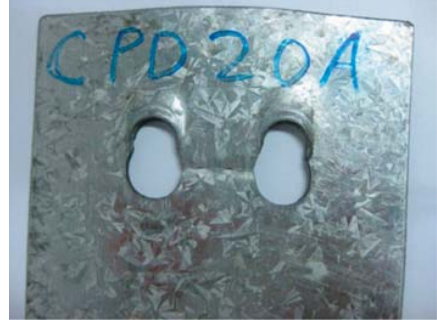

(a) Block shear failure

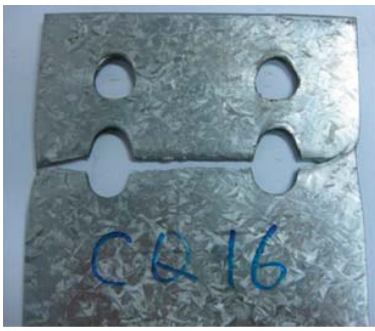

(b) Net section fracture
Fig. 12. Two most critical failure modes: (a) block shear failure; (b) net section fracture

Each of the competing block shear capacity equations is compared against the net section tension capacity given by

$$
P_{p}=F_{u}\left[\sum A_{n i}\left(0.9+0.1 \frac{d}{p_{2}}\right)+\sum A_{n o}\left(0.9+0.05 \frac{d}{e_{2}}\right)\right]
$$

where $A_{n i}=$ net section between bolt holes, and $A_{n o}=$ either of the two net sections flanking the group of bolts. The variables $p_{2}$ and $e_{2}$ are defined in Fig. 3. Eq. (4) has been demonstrated by Teh and Gilbert (2012) to predict the net section tension capacity of bolted connections in the present steel materials with very high accuracy.

In addition to assessing the different shear failure planes assumed in Eqs. (1)-(3), an assessment of a modified version of Eq. (3) that uses the mean between the yield stress and the tensile strength

$$
P_{p}=F_{u} \sum A_{n t}\left(0.9+0.1 \frac{d}{p_{2}}\right)+0.3\left(F_{y}+F_{u}\right) A_{a v}
$$

was also performed. The approach of using the mean between the yield stress and the tensile strength to account for shear strain hardening was proposed by Driver et al. (2006).

All the specimens in Tables 5 and 6 failed in block shear. A letter $\mathrm{N}$ in a cell of these tables indicates that the equation wrongly predicts the governing failure mode to be net section fracture. Eq. (1) missed the block shear failure mode of most specimens because it overestimates the shear yielding resistance, especially for the specimens with multiple rows of bolts. This outcome reinforces the indication of Tables 2 and 3 and the FEA results described in the preceding section, that the use of the gross shear planes depicted in Fig. 1(a) overestimates the shear area available for resisting block shear failure.

It may be noted that if the in-plane shear lag factor in Eq. (3) is applied to the tensile resistance term of Eq. (1), then the number of misses will decrease by three for each series, resulting in a total of 22 misses instead of 28. If the shear lag factor in Eq. (4) is neglected, reducing the equation into the conventional net section tension capacity where the net section is assumed to be fully effective, then the number of misses by Eq. (1) will decrease by five for each series, resulting in a total of only 18 misses.

Eq. (5), which uses the mean between the yield stress and the tensile strength in conjunction with the active shear planes depicted in Fig. 2, missed the block shear failure mode of seven specimens. This outcome suggests that it is advisable to simply use the yield stress to determine the shear yielding resistance, as indicated in Eq. (3).

All the four specimens in Table 7 failed in net section fracture. A letter $\mathrm{B}$ in a cell indicates that the equation wrongly predicts the
Table 5. Predicted Failure Mode for Series A Specimens Failing in Block Shear

\begin{tabular}{lccccccccccc}
\hline & & & & & & \multicolumn{3}{c}{ With } & Eq. \\
\cline { 6 - 11 } Specimen & $W(\mathrm{~mm})$ & $p_{2}(\mathrm{~mm})$ & $t(\mathrm{~mm})$ & $e_{1}(\mathrm{~mm})$ & $d_{h}(\mathrm{~mm})$ & 1 & 2 & 3 & 5 \\
\hline CPD14 & 100 & 33 & 1.5 & 50 & 17 & $\mathrm{~N}$ & $\mathrm{~B}$ & $\mathrm{~B}$ & $\mathrm{~N}$ \\
CPD15 & 100 & 33 & 3.0 & 50 & 13 & $\mathrm{~N}$ & $\mathrm{~B}$ & $\mathrm{~B}$ & $\mathrm{~N}$ \\
CPD16 & 100 & 33 & 3.0 & 50 & 17 & $\mathrm{~N}$ & $\mathrm{~B}$ & $\mathrm{~B}$ & $\mathrm{~B}$ \\
CPD18 & 120 & 40 & 1.5 & 50 & 17 & $\mathrm{~N}$ & $\mathrm{~B}$ & $\mathrm{~B}$ & $\mathrm{~B}$ \\
CPD19 & 120 & 40 & 3.0 & 50 & 13 & $\mathrm{~B}$ & $\mathrm{~B}$ & $\mathrm{~B}$ & $\mathrm{~B}$ \\
CPD20a & 120 & 40 & 3.0 & 50 & 17 & $\mathrm{~B}$ & $\mathrm{~B}$ & $\mathrm{~B}$ & $\mathrm{~B}$ \\
CPD20b & 120 & 40 & 3.0 & 50 & 17 & $\mathrm{~B}$ & $\mathrm{~B}$ & $\mathrm{~B}$ & $\mathrm{~B}$ \\
CPD22a & 100 & 26 & 1.5 & 50 & 17 & $\mathrm{~N}$ & $\mathrm{~B}$ & $\mathrm{~B}$ & $\mathrm{~B}$ \\
CPD22b & 100 & 26 & 1.5 & 50 & 17 & $\mathrm{~N}$ & $\mathrm{~B}$ & $\mathrm{~B}$ & $\mathrm{~B}$ \\
CPD23a & 100 & 26 & 3.0 & 50 & 13 & $\mathrm{~N}$ & $\mathrm{~B}$ & $\mathrm{~B}$ & $\mathrm{~B}$ \\
CPD23b & 100 & 26 & 3.0 & 50 & 13 & $\mathrm{~N}$ & $\mathrm{~B}$ & $\mathrm{~B}$ & $\mathrm{~B}$ \\
CPD24a & 100 & 26 & 3.0 & 50 & 17 & $\mathrm{~N}$ & $\mathrm{~B}$ & $\mathrm{~B}$ & $\mathrm{~B}$ \\
CPD24b & 100 & 26 & 3.0 & 50 & 17 & $\mathrm{~N}$ & $\mathrm{~B}$ & $\mathrm{~B}$ & $\mathrm{~B}$ \\
CPD26a & 120 & 26 & 1.5 & 50 & 17 & $\mathrm{~B}$ & $\mathrm{~B}$ & $\mathrm{~B}$ & $\mathrm{~B}$ \\
CPD26b & 120 & 26 & 1.5 & 50 & 17 & $\mathrm{~B}$ & $\mathrm{~B}$ & $\mathrm{~B}$ & $\mathrm{~B}$ \\
CPD27 & 120 & 26 & 3.0 & 50 & 13 & $\mathrm{~B}$ & $\mathrm{~B}$ & $\mathrm{~B}$ & $\mathrm{~B}$ \\
CPD28a & 120 & 26 & 3.0 & 50 & 17 & $\mathrm{~B}$ & $\mathrm{~B}$ & $\mathrm{~B}$ & $\mathrm{~B}$ \\
CPD28b & 120 & 26 & 3.0 & 50 & 17 & $\mathrm{~B}$ & $\mathrm{~B}$ & $\mathrm{~B}$ & $\mathrm{~B}$ \\
CPD36 & 130 & 45 & 3.0 & 30 & 17 & $\mathrm{~B}$ & $\mathrm{~B}$ & $\mathrm{~B}$ & $\mathrm{~B}$ \\
Misses & - & - & - & - & - & 10 & 0 & 0 & 2 \\
\hline
\end{tabular}

Note: $\mathrm{N}=$ net section fracture; $\mathrm{B}=$ block shear failure.

Table 6. Predicted Failure Mode for Series B Specimens Failing in Block

\begin{tabular}{|c|c|c|c|c|c|c|c|c|c|}
\hline \multirow[b]{2}{*}{ Specimen } & \multirow[b]{2}{*}{$W(\mathrm{~mm})$} & \multirow[b]{2}{*}{$p_{2}(\mathrm{~mm})$} & \multirow[b]{2}{*}{$t(\mathrm{~mm})$} & \multirow[b]{2}{*}{$e_{1}(\mathrm{~mm})$} & \multirow[b]{2}{*}{$d_{h}(\mathrm{~mm})$} & \multicolumn{4}{|c|}{ With Eq. (4) } \\
\hline & & & & & & 1 & 2 & 3 & 5 \\
\hline CQ2a & 120 & 26 & 1.5 & 50 & 17 & $\mathrm{~N}$ & B & N/B & $\mathrm{N}$ \\
\hline CQ2b & 120 & 26 & 1.5 & 50 & 17 & $\mathrm{~N}$ & B & N/B & $\mathrm{N}$ \\
\hline CQ3 & 120 & 26 & 3.0 & 50 & 13 & $\mathrm{~N}$ & B & B & $\mathrm{N}$ \\
\hline CQ4 & 120 & 26 & 3.0 & 50 & 17 & $\mathrm{~N}$ & B & B & $\mathrm{N}$ \\
\hline CQ5a & 130 & 40 & 1.5 & 30 & 13 & $\mathrm{~N}$ & B & B & B \\
\hline CQ5b & 130 & 40 & 1.5 & 30 & 13 & $\mathrm{~N}$ & B & B & B \\
\hline CQ6a & 130 & 40 & 1.5 & 30 & 17 & $\mathrm{~N}$ & B & B & B \\
\hline CQ6b & 130 & 40 & 1.5 & 30 & 17 & $\mathrm{~N}$ & B & B & B \\
\hline CQ7 & 130 & 40 & 3.0 & 30 & 13 & B & B & B & B \\
\hline CQ8 & 130 & 40 & 3.0 & 30 & 17 & $\mathrm{~N}$ & B & B & B \\
\hline CQ9b & 130 & 55 & 1.5 & 30 & 13 & $\mathrm{~N}$ & B & B & B \\
\hline CQ10a & 130 & 55 & 1.5 & 30 & 17 & $\mathrm{~N}$ & B & B & B \\
\hline CQ10b & 130 & 55 & 1.5 & 30 & 17 & $\mathrm{~N}$ & B & B & B \\
\hline CQ11 & 130 & 55 & 3.0 & 30 & 13 & $\mathrm{~N}$ & B & B & B \\
\hline CQ12 & 130 & 55 & 3.0 & 30 & 17 & $\mathrm{~N}$ & B & B & B \\
\hline CQ17 & 120 & 45 & 1.5 & 30 & 13 & $\mathrm{~N}$ & B & B & B \\
\hline CQ18 & 130 & 50 & 1.5 & 30 & 13 & $\mathrm{~N}$ & B & B & B \\
\hline CQ19 & 120 & 55 & 3.0 & 25 & 13 & $\mathrm{~N}$ & B & B & $\mathrm{N}$ \\
\hline CQ20 & 120 & 55 & 3.0 & 25 & 17 & $\mathrm{~N}$ & B & B & B \\
\hline Misses & - & - & - & - & - & 18 & 0 & 0 & 5 \\
\hline
\end{tabular}
Shear

Note: $\mathrm{N}=$ net section fracture; $\mathrm{B}=$ block shear failure

specimen to fail in block shear. Eq. (2) missed the net section tension fracture mode of all specimens because it underestimates the shear yielding resistance to block shear failure as a result of its use of the net shear planes depicted in Fig. 1(b). It can be verified that this outcome is independent of the presence of the shear lag factor in either Eq. (4) or the tensile resistance term of Eq. (2) and whether the coefficient of 0.577 in Eq. (2) is replaced with 0.6. 
Table 7. Predicted Failure Mode for Series B Specimens Failing in Net Section Fracture

\begin{tabular}{lcccccccccc}
\hline & & & & \multicolumn{4}{c}{ With Eq. (4) } \\
\cline { 5 - 10 } Specimen & $W(\mathrm{~mm})$ & $p_{2}(\mathrm{~mm})$ & $t(\mathrm{~mm})$ & $e_{1}(\mathrm{~mm})$ & $d_{h}(\mathrm{~mm})$ & 1 & 2 & 3 & 5 \\
\hline CQ1a & 120 & 26 & 1.5 & 50 & 13 & $\mathrm{~N}$ & $\mathrm{~B}$ & $\mathrm{~N}$ & $\mathrm{~N}$ \\
CQ1b & 120 & 26 & 1.5 & 50 & 13 & $\mathrm{~N}$ & $\mathrm{~B}$ & $\mathrm{~N}$ & $\mathrm{~N}$ \\
CQ14 & 130 & 65 & 1.5 & 30 & 17 & $\mathrm{~N}$ & $\mathrm{~B}$ & $\mathrm{~N}$ & $\mathrm{~N}$ \\
CQ16 & 130 & 65 & 3.0 & 30 & 17 & $\mathrm{~N}$ & $\mathrm{~B}$ & $\mathrm{~N}$ & $\mathrm{~N}$ \\
Misses & - & - & - & - & - & 0 & 4 & 0 & 0 \\
\hline
\end{tabular}

Note: $\mathrm{N}=$ net section fracture; $\mathrm{B}=$ block shear failure.

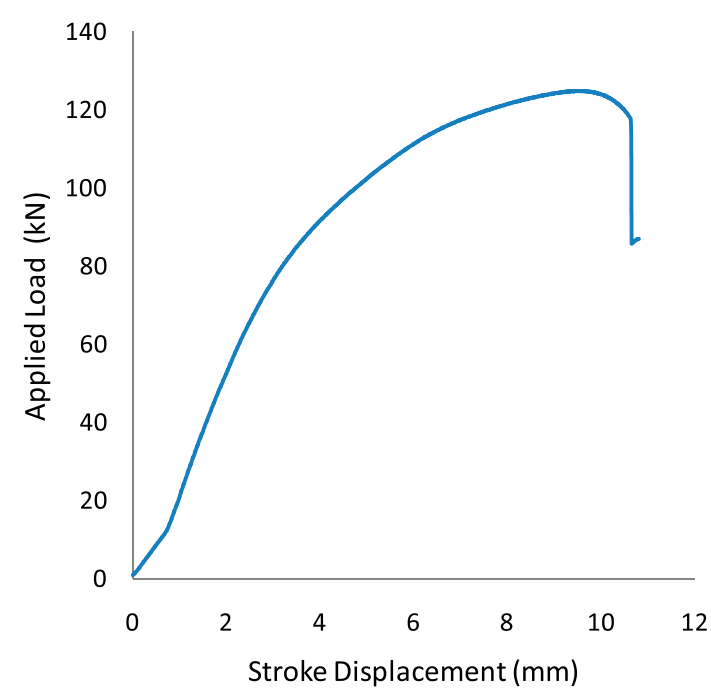

Fig. 13. Load-deflection graph of CPD20a

The only equation that never predicted an incorrect failure mode is Eq. (3). For Specimens CQ2a and CQ2b in Table 6, the block shear capacity given by the equation is the same as the net section tension capacity given by Eq. (4).

Following a reviewer's comment, the load-deflection graph of Specimen CPD20a is shown in Fig. 13 to ascertain that it failed in block shear rather than bearing. A bearing failure would have been associated with an extended plateau of the load-deflection curve followed by a gently downward sloping portion, in contrast to the response exhibited by CPD20a. The bearing capacity of the specimen was more than $50 \%$ greater than the ultimate test load.

\section{Conclusions}

The repeated changes to the design provision for determining the block shear capacity of a bolted connection stems from two major factors. The first, the uncertainty regarding the possible mechanisms for block shear failures, has recently been resolved by the authors. The second concerns the inconsistent definitions used for the failure planes, depending on the assumed failure mechanism. In reality, the failure planes are unique for the block shear failure mode, even if different mechanisms exist.

This paper uses geometrically and materially nonlinear contact FEA to confirm that the active shear planes lie between the gross and the net shear planes, as indicated by the experimental evidence obtained by other researchers. The FEA results also indicate that the in-plane shear stresses approach zero toward the downstream end of the connection.

The use of the active shear planes in conjunction with the shear yield stress was previously demonstrated by the authors to result in significantly more accurate estimates for the block shear failure loads of laboratory test specimens compared with the use of the gross or the net shear planes. In this paper, the use of the active shear planes is also shown to correctly predict the governing failure modes of all test specimens, whether block shear failure or net section fracture, in contrast to the use of the gross or the net shear planes. The present work resolves the hypothetical uncertainty of whether the measured material (and geometric) properties used in the calculations of the block shear capacities, which were significantly different from the nominal values, unduly favor the equation proposed by the authors.

The block shear equation previously proposed by the authors, which makes use of the active shear planes, is supported by the present FEA results and the present comparison against alternative equations in predicting the correct failure modes, in addition to independent experimental evidence and the authors' previous demonstration of the equation's accuracy in estimating the block shear failure loads of laboratory test specimens.

Future tests are being planned to include block shear failures of angle braces bolted at one leg and single-shear connections.

\section{Acknowledgments}

The authors thank John Kralic, Manager (Lysaght Research and Technology, Bluescope Steel Limited), for supplying the G450 sheet steel materials used in the present work; Gregory Hancock, Emeritus Professor (University of Sydney), for expert input concerning the state of the art of bolted connection design in coldformed sheet steel; and Chris Cook, Dean of Engineering, and Muhammad Hadi, Head of the Advanced Structural Engineering and Construction Materials Group (University of Wollongong), for supporting the laboratory tests that were conducted in the High Bay Laboratory of the Faculty of Engineering. The specimens were fabricated by Ritchie McLean.

\section{References}

ABAQUS 6.9 [Computer software]. Providence, RI, Dassault Systèmes.

AISC. (1978). Specification for the design, fabrication and erection of structural steel for buildings, Chicago.

AISC. (1986). Load and resistance factor design specification for structural steel buildings, Chicago.

AISC. (1999). Load and resistance factor design specification for structural steel buildings, Chicago.

AISC. (2010). "Specification for structural steel buildings." ANSI/AISC 36010, Chicago.

American Iron and Steel Institute (AISI). (2010). "North American specification for the design of cold-formed steel structural members, 2007 edition with supplement 2." AISI S100-07 W/S2-10, Washington, DC.

Birkemoe, P. C., and Gilmor, M. I. (1978). "Behavior of bearing-critical double-angle beam connections.” Eng. J. AISC, 15(3), 109-115.

Clements, D. D. A. (2011). "Block shear capacity of bolted connections in cold-reduced steel sheets.” B.E. thesis, Univ. of Wollongong, Wollongong, Australia.

Cunningham, T. J., Orbison, J. G., and Ziemian, R. D. (1995). “Assessment of American block shear load capacity predictions." J. Construct. Steel Res., 35(3), 323-338.

Driver, R. G., Grondin, G. Y., and Kulak, G. L. (2006). "Unified block shear equation for achieving consistent reliability." J. Construct. Steel Res., 62(3), 210-222. 
European Committee for Standardization (CEN). (1992). "Design of steel structures, Part 1.8: Design of joints." Eurocode 3, EN 1993-1-8, Brussels, Belgium.

European Committee for Standardization (CEN). (2005). "Design of steel structures, Part 1.8: Design of joints." Eurocode 3, EN 1993-1-8, Brussels, Belgium.

Franchuk, C. R., Driver, R. G., and Grondin, G. Y. (2003). "Experimental investigation of block shear failure in coped steel beams." Can. J. Civ. Eng., 30(5), 871-881.

Hardash, S. G., and Bjorhovde, R. (1985). "New design criteria for gusset plates in tension." Eng. J. AISC, 22(2), 77-94.

Huns, B. B. S., Grondin, G. Y., and Driver, R. G. (2006). "Tension and shear block failure of bolted gusset plates." Can. J. Civ. Eng., 33(4), 395-408.

Kim, T. S., and Kuwamura, H. (2007). "Finite element modelling of bolted connections in thin-walled stainless steel plates under static shear." Thinwalled Struct., 45(4), 407-421.
Liao, M., Okazaki, T., Ballarini, R., Schultz, A. E., and Galambos, T. V. (2011). "Nonlinear finite-element analysis of critical gusset plates in the I-35W Bridge in Minnesota.” J. Struct. Eng., 137(1), 59-68.

Seleim, S., and LaBoube, R. A. (1996). "Behavior of low ductility steels in cold-formed steel connections." Thin-walled Struct., 25(2), 135150 .

Standards Australia/Standards New Zealand (SA/SNZ). (2005). "Coldformed steel structures." AS/NZS 4600:2005, Homebush, New South Wales, Australia.

Teh, L. H., and Clements, D. D. A. (2012). "Block shear capacity of bolted connections in cold-reduced steel sheets." J. Struct. Eng., 138(4), 459-467.

Teh, L. H., and Gilbert, B. P. (2012). "Net section tension capacity of bolted connections in cold-reduced steel sheets." J. Struct. Eng., 138(3), 337-344.

Topkaya, C. (2004). "A finite element parametric study on block shear failure of steel tension members.” J. Construct. Steel Res., 60(11), 16151635. 